\title{
Формирование международного парламентского права
}

\author{
Саидов A.X."
}

Международныс организации играют весьма важную роль в современном мире. К началу ХХІ века они представляाот собой сложившуюся систему, в центре которой находится Организация Объединенных Наций. Главная роль, которую международные организации играют в мировой политике, - это ограничение международной анархии, внесение в международные отношения упорядоченности, стабильности, формирование климата доверия между взаимодействующими субъектами.

Отличительной чертой современных международных отношений является продолжающийся рост числа международных организаций. «За последние 50 лет количество межправительственных организаций (МПО) увеличилось более чем в шесть раз, что составляет прирост в 100\% за каждые 17 лет» ${ }^{1}$. Работу по составлению перечня международных организаций ведет Союз международных ассоциаций, публикуя его в специальных ежегодниках. В частности, в 39-м издании «Ежегодника международных ассоциаций» содержатся краткие сведения о 25542 различного рода международных (межправительственных и неправительственных) организаця ${ }^{2}$. Существует обширная литература по теории и практике деятельности международных организаций, опубликованы значительные труды по некоторым из них, в первую очередь по ООН, ЕС, Совету Европы, ОБСЕ.

Общепризнанно, что сложилась и развивается самостоятельная отрасль современного международного публичного права - право меж-

${ }^{*}$ Саидов Акмаль Холматович - д.ю.н., профессор международного и сравнительного права, зав. кафедрой ЮНЕСКО по правам человека, демократии, мира, толерантности и международному взаимопониманию Университета мировой экономики и дипломатии Министерства иностранных дел Республики Узбекистан, Чрезвьгчайный и Полномочный Посол.

${ }^{1}$ Международные отношения: теории, конфликты, организации: Учебное пособие / Под ред. П.А. Цыганкова. М., 2004. С. 7.

${ }^{2}$ Yearbook of International Associations: 2002/2003. Guide to Global and Civil Society Networks. Ed. 39.-K.G. Saur München, 2003.-Vol. 1A. XII-P. 1242; Vol. 1B. -P. 1243-2674. 
дународных организаций ${ }^{3}$, которое заняло постоянное место в учебниках по международному праву ${ }^{4}$.

Первые международные организации регионального и универсального характера являлись чисто межправительственными и не имели парламентских учреждений. Они были форумами сотрудничества государств вне какого-либо межлународного парламентского контроля.

После Второй мировой войны интенсификация интеграционных процессов в мире положила начало широкой институциализации идеи международного парламентского представительства в виде создания международных парламентских ассамблей-представительньх учреждений многостороннего парламентаризма.

Как известно, развитие сотрудничества между государствами, их интеграция закономерно предполагают передачу ряда полномочий, традиционно связываемых с государственным суверенитетом, межгосударственным и наднационалыным органам. Как следствие, данные области компетенции государств выходят в значительной мере из-под обычного политического и парламентского контроля наций и народов. Чем больше полномочий приобретают межгосударственные и наднациональные исполнительные органы, тем острее становится необходимость осуществления международного парламентского контроля вместо контроля со стороны национальных представительных органов, который последние осуществлять более не в состоянии. Это становится особенно важньм в связи со стремлением народов расширить свой контроль над вопросами, которые оказывают непосредственное воздействие на их повседневное бытие ${ }^{5}$.

${ }^{3}$ См.: Шибаева Е.А. Право международных организаций: вопросы теории. М., 1986. 160 с.; Актуальные проблемы деятельности международных организаций: теория и практика. М., 1982.351 с.; Нешатаева Т.Н. Международные организации и право. М., 1999. Amerasinghe C.F. Principles of the International Law and International Organizations. Cambridge, 1996; Schermais H., Blokker N. International Institutional Law. 3-d ed. The Hague, London, Boston, 1995.

${ }^{4}$ См.: Международное право: Учебник. Отв. ред. Ю.М. Колосов, Э.С. Кривчикова. М., 2000. С. 212-287; Международное право: Учебник/Отв. ред. В.И. Кузнецов. М., 2001. С. 370-409; Лукашук И.И. Международное право. Особенная часть: Учебник. Изд. 3-е, перераб. и доп. М., 2005. С. 23-68; Международное публичное право: Учебник / Отв. ред. К.А. Бекяшев. 3-е изд., перераб. и доп. М., 2004. С. 341-462; Каламкарян Р.А., Мигачев Ю.П. Международное право: Учебник. М., 2004. С. 218-295 и др. ${ }^{5}$ Хабаров С.А. Европейскиепарламентские организации (правовые аспекты) // Государство и право. 1997. № 1. С. 92. 
До середины ХХ века международное парламентское сотрудничество не было развито. За этот период появляются единичные организации, занимающиеся вопросами развития межпарламентских связей (например, Парламентская Ассочиация (Британского) Содружества, Ассочиация Генеральных секретарей парламентов, Международная Комиссия по истории представительных и парламентских институтов, Общество Хансарда за парламентское правление).

После Второй мировой войны началось бурное развитие международных парламентских организаций. Характерной особенностыю этого развития стало то, что межпарламентские организации (МПО) либо носили региональный характер, либо имели под собой политико-идеологическую подоплеку (Парламентская Ассамблея Совета Европь, Европейский Парламент, Североатлантическая ассамблея, Межпарламентский консультативный совет Бенилюкса, Латиноамериканский парламент, Межспарламентская организачия АСЕАН, Андский парламент и т.д.). На наш взгляд, это предопределило успешность функционирования этих организаций, т.к. они не являлись такими тучными бюрократизированными организациями, как ООН, и в то же время благодаря своей определенной идеологической направленности всегда имели средства существования и политическую поддержку.

Распад колониализма и возникновение развивающихся стран привели к налаживанию между ними связей иного порядка, чем прежде. В отношении межпарламентского сотрудничества эти связи развивались в двух направлениях: между бывшими колониями (например, Союз парламентариев Азии и бассейна Тихого океана, Арабский межпарламентский союз, Африканский парламентский Союз) и между развиваюшимися странами и их бывшими колонизаторами (Парламентскал Ассочиация за евро-арабское сотрудничество, Парламентскал Ассамблея франкоговорящих парламентариев).

Новой волной развития международных парламентских организаций стал конец 1980-х и 1990-е годы. Этот период ознаменовался развалом т.н. социалистического лагеря и формированием новых независимых государств на огромной части евразийского материка. Причем если новые государства Централыной и Восточной Европы стремились к налаживанию сотрудничества с европейскими МПО (Парламентская Ассамблея Совета Европь, Парламентская Ассамблея ОБСЕ), то бывшие республики СССР стали создавать и свои региональные МПО, крупнейшей из которых стала Межпарламентская Ассамблея СНГ. 
Практически все республики бывшего Советского Союза в болышей или меньшей степени находились в состоянии политического и экономического упадка, что вызывало необходимость искать возможные пути выхода из сложившейся неблагоприятной ситуации. Один из выходов, разумеется, состоял в частичном восстановлении связей между этими государствами, которые некогда составляли одно целое. И одним из направлений сотрудничества стало сотрудничество между национальными парламентами этих стран и образование ряда региональных МПО. Их особенностьо является То, чТо они объединяют несколько, подчас всего два, государства (Балтийская Ассамблея, Парламентское собрание Союза Белоруссии и России, Межпарламентская Ассамблея Евразийского экономического сообщества и т.д.).

Кроме того, последнее десятилетие XX в. и начало третьего столетия охарактеризовались созданием многочисленных МПО во всем мире, что в немалой степени связано с процессами глобализации. Так, с 1991 по 2005 г. в мире образовалось более двадцати новых международньх парламентских организаций (Центральноамериканский парламент, Совместная парламентская комиссия Южного Общего Рын$к а$, Совместный парламентский Комитет Европейского экономического пространства, Ассочиация азиатских парламентов за мир, Американский межспарламентский форум и др.). Возникли международные парламентские организации на религиозной основе: Европейская межпарламентская ассамблея православия, Парламентский Союз стран - членов Организации Исламской Конференции.

Создание новых МПО продолжается. В рамках Конференции МПС (Маракеш, 17-23 марта 2002 г.) состоялась встреча представителей стран - участниц Межпарламентской конференции по безопасности и сотрудничеству в Средиземноморье, на которой обсуждался вопрос создания Парламентской Ассамблеи стран Средиземноморья, а в 2005 г. в Иордании состоялась инаугурационная сессия этой Ассамблеи ${ }^{6}$. 21-22 ноября 2002 г. в г. Оттаве (Канада) более ста парламентариев из 70 стран провели Международную Конференцию Парламентариев, главнойцелью которой было развитие межпарламентского диалога всех регионов мира по внедрению Программных действий Международной конференции по народонаселению и развитию. 23-26 июля 2002 г. в Сеуле (Республика Корея) прошла Учредительная Генеральная Ас-

${ }^{6}$ Establishment of the Parliamentary Assembly of the Mediterranean // The World of Parliaments. 2005. № 17. P. 8. 
самблея Международной Ассоциации парламентариев за информационную технологию.

Несмотря на многообразие МПО, они имеют много общего. Общими для международных межпарламентских организаций являготся:

во-первых, наличие правовой основы их деятельности (Устава, Хартии, соглашений);

во-вторых, МПО состоят из государств-членов и при определенных обстоятельствах также из международных организаций; такое членство может быть универсальным или региональным;

в-третьих, МПО имеют сопоставимые цели, принципы и функции, направленные на развитие межпарламентских связей;

в-четвертых, межпарламентские организации имеют своеобразную структуру (конференция, исполнительный комитет, секретариат, комитеты и комиссии).

Таким образом, в начале XXI века межпарламентские организации стали важным фактором развития современных международных отношений. Они призваны создать нормативно-правовую базу для конструктивного международного парламентского сотрудничества; усилилось к ним доверие общественного мнения. Сегодня межпарламентское сотрудничество распространяется почти на все вопросы, которые еще несколько лет назад нельзя было затрагивать из политико-идеологических соображений.

В настоящее время внешнеполитическая активность национальных парламентов усиливается. Это проявляется, в частности, в увеличении числа международных конференций с участием парламентариев. Одним из проявлений этой тенденции стала активизация работы парламентских делегаций в рамках международных организаций и возникновение новых межпарламентских организаций.

Национальные парламенты играют весьма заметную роль как в образовании международных межправителственных организаций, так и в деятельности международных неправительственных организаций парламентариев ${ }^{7}$. Налищо тенденщия расширения направлений деятельности, функций и компетенции международных парламентских организаций, увеличения их видового разнообразия. Они существенно дополняют друг друга, хотя каждая из них обладает своей специфической сферой деятельности и различным объемом полномочий.

${ }^{7}$ См.: Кутейников А.Е. Национальные парламенты и международные организации // Вестник Межпарламентской Ассамблеи. 1999. № 2. С. 121-135. 
Развитие парламентского сотрудничества между государствами привело к разветвлению различных по своему содержанию видов межпарламентских связей. В частности, за последнго четверть века значителын расширились международные межпарламентские отношения. Являясь одной из форм международного сотрудничества между государствами, межпарламентские отношения вместе с тем имеют специфические особенности. Учет этих особенностей позволяет объьединить межпарламентские отношения в одну группу международных отношений и выявить специфику их международно-правового регулирования.

В настоящее время необходимо описать и систематизировать международные парламентские отношения, подвергнуть их анализу с целью обобщить практику и установить общие принципы, на которые опираются эти отношения. Проблематика международных межпарламентских организаций заинтересовала представителей как науки международного права, так и науки национального парламентского права.

Предметом межлународного парламентского права являготся международные межпарламентские отношения. Вместе с тем многообразие международных межпарламентских отношений - это многообразие в единстве. Возникающие в международной жизни межпарламентские отношения характеризуются целым рядом признаков, присуших всем видам этих отношений. Такими родовыми признаками следует признать:

во-первых, обязательное участие в них парламентариев как народных избранников, т.е. представительный характер этих отношений;

во-вторых, обязательное участие в них национальных парламентов и международных межпарламентских организаций;

в-третьих, возникновение этих отношений во внешней деятельности национальных парламентов.

Международные межпарламентские организации содействуют повышению эффективности и ответственности международных органов в решении глобальных проблем современности. Они представляют собой сложившуюся систему, в центре которой в настоящее время находятся Организация Объединенньх Наций и Межпарламентский союз. Ежегодные встречи Межпарламентского союза в ООН являются полезным способом расширения сотрудничества между членами национальных парламентов по международным вопросам. Разумеется, существование международных межпарламентских организаций во многом зависит от воли суверенных государств, они тем не менее 
иг рают в сфере международной жизни очень важную самостоятельную роль, и эта роль становится всеболее значительной и разнообразной.

В настоящее время в юридической науке уделяется все большее внимание развитиюо направления исследований, которое получило название «парламентское право» ${ }^{8}$. И хотя споры о статусе этого направления в системе правоведения, о круге относящихся к его ведению проблем (очевидно, такие споры на первых этапах неизбежны) продолжаются, обшепризнанно, что парламентская теория и практика, как национальная, так и международная, существенно важны для дальнейшего развития юридической науки. Современные проблемы парламентского права и тенденции развития парламентаризма обсуждались на XIV Международном конгрессе сравнительного права в Афинах ${ }^{9}$.

Парламенты современных государств, наряду с выполнением своих традиционных функцй, осуществлягот весьма активную международнуго деятельность и вместе с главами государств, правительствами, дипломатическими и консульскими службами являются внешнеполитическими органами. Они влияют на международные дела и внешнюю политику государства через бюджет и механизмы законотворческой деятельности. Парламенты принимают законы, регламентирующие внешние сношения. В ряде случаев парламенты участвугт в назначении должностных лиц, в обязанности которых входит осуществление внешних сношений: глав государств и правительств, министров, послов и представителей при международных организациях. Осуществляется парламентский контроль над работой государственных орга-

\footnotetext{
${ }^{8}$ Фактически ужесегодня можно Говорить о том, что в болышинстве стран мира сформировалась самостоятельная отрасль права - парламентское право. Это вполне объяснимо стремлением ученых обосновать устойчивый характер в одних странах и формирующийся в других странах комплекс правовых актов и норм, регламентирующих организацию и деятельность собственно национального парламента. См.: Парламентское право России: Учеб. пособие / Под. ред. Т.Я. Хабриевой. 2-е изд. М., 2003; Любимов А.П. Парламентское право России: Учеб. пособие. 3-е изд., перераб. и доп. М., 2002; Очерки парламентского права / Подред. Б.Н. Топорнина. М., 1993; Проблемы парламентского права России / Подред. Л.М. Иванова, 1996; Булаков О.Н. Парламентскоеправо Российской Федерации. М., 2004; Крутоголов М.А., Ковлер А.И. Парламентское право Францин //Очерки парламентского права. М., 1993; Керимов А.Д. Парламентское право Франции. М., 1998; Урьяс Ю.П. Парламентское право ФРГ // Очерки парламентского права. М., 1993 и др.

${ }^{9}$ CM.: L'Évolution Recent du Parliamentarism. XIVe Congrès International de droit comparé. Athens. August 1999. Rapports Generak et nationaux / Prepare par Alessandro Pizzorusso. The Hague, London, Boston. 1996. VIII, 257 p.
} 
нов, выполняющих международные обязательства. Парламенты ратифицируют заключенные государствами международные договоры, которые только после ратификации приобретают статус законов ${ }^{10}$.

Это все доказывает, что современное общество, любая его сфера невозможна без парламента. Во всех конституциях государств мира закреплению статуса парламента отводится значительное место ${ }^{11}$. Свободно и честно избранный парламент является наилучшей гарантией человеческого достоинства и процветания граждан.

Из различных определений национального парламентского права можно привести следугщее: парламентское право - это особая система юридических принципов и норм, регулирующих внутреннее устройство парламента и связанные с ним организационные отношения, сам процесс парламентской деятельности, его взаимоотношения с другими органами государственной власти и избирательным корпусом ${ }^{12}$. Национальное парламентское право регулирует парламентско-правовые отношения на различных уровнях - как внутрипарламентском, так и между парламентом и другими высшими органами государства, между парламентом и избирательным корпусом. В предмет национального парламентского права входят также вопросы как двустороннего, так и многостороннего межпарламентского сотрудничества ${ }^{13}$. Более того, к числу источников парламентского права относятся также общепризнанные принципы и нормы международного права в области парламентаризма.

Несомненно, что фактором, стимулировавшим активизацию этого направления, явились становление парламентаризма и межпарламентских организаций, а также развитие институтов парламентской демократии в современном мире. Давая оценку в исторической ретроспективе, можно утверждать, что международные межпарламентские

${ }^{10}$ См.: Лукашук И.И. Внешняя политика: Президент и парламент // Государство и право. 1996. № 7. С. 138-144; Романов Р. Роль парламента в государственном управлении // Президент. Парламент. Правительство. 1998. № 5. С. 41 -43; Кутейников А.Е. Национальные парламенты и международные организации // Вестник Межпарламентской Ассамблеи. 1999. № 2. С. 120-121.

${ }^{11}$ См.: Саидов А.Х. Национальные парламенты мира:Энциклопедический справочник. М., 2005.

${ }^{12}$ Хабриева Т.Я. Понятие и место парламентского права России в системе права // Журнал российского права. 2002. № 9. С. 3, 5-6.

${ }^{13}$ См.: Парламентское право России: учебное пособие/Под ред. Т.Я. Хабриевой. 2-е изд. М., 2003. С. 359-383 (Глава VII. «Межпарламентское сотрудничество». Автор главы А.С. Автономов). 
организации состоялись как важный политико-правовой институт и стали важным средством глобального управления международным сообществом. Они превратились в один из элементов современной межлународной жизни.

Однако вопросы создания, функционирования и организации внутренней структуры, компетенции, внешних связей и публикации в межпарламентских организациях освещены недостаточно. Ряд исследований монографического плана посвящен отдельным или группам межпарламентских организаций. Среди них следует указать на монографии Е.А. Шибаевой и В.Л. Швецова, посвященные Межпарламентскому Союзу, И.С. Крыловой, Ю.М. Батурина и А.И. Ковлера - Европейскому парламенту, В.С. Котляра -Северному Совету ${ }^{14}$, Г.Г. Шинкарецкой, С.В. Ерохова, М.И. Кротова, Е.Г. Моисеева - Межпарламентской Ассамб̄лее СНГ ${ }^{15}$.

Важным источником информации по межпарламентским организациям являготся весьма незначительные по объему краткие справочники «Международные парламентские организации», посвященные историко-политическим аспектам функционирования ряда МПО, несколько изданий которых было подготовлено в Верховном Совете СССР (России) в 1991, 1992 и 1994 годах ${ }^{16}$.

Первыми обстоятелыными исследованиями монографического плана являются работы С.А. Хабарова. В своей кандидатской диссертации и в двух книгах он достаточно полно исследовал весьма широкий

\footnotetext{
${ }^{14}$ См.: Шибаева Е.А. Межпарламентский союз. М., 1957. 148 с.; Швецов В.Л. Межпарламентский союз. Изд. 2-е, переработ. и доп. М., 1966. 240 с.; Межпарламентский союз: Устав и правила процедуры. М., 1984. 108 с.; Батурин Ю.М. Европейский парламент: статус и современная роль // Сов. гос. и право. 1985. № 1. С. 85-89; Котляр В.С. Северный Совет: структура, деятельность. М., 1973. 144 с.; Крылова И.С. Европейский парламент: (правовой статус). М.: Наука, 1987. 191 с.; Ковлер А.И., Крылова Н.С. Европейский парламент // Парламенты мира. М., 1991; Хабарова Т., Хабаров С. Европейский парламент // Президент. Парламент. Правительство. 1997. № 1. С. 74-75.

${ }^{15}$ См.: Шинкарецкая Г.Г. Межпарламентская Ассамблея Содружества Независимых Государств на фоне межпарламентских организаций других интеграционных объединений // Государство и право. 1997. № 4. С. 83-90; Ерохов С.В. Межпарламентская Ассамблея СНГ: становление и перспективы // Государство и право. 1994. № 8-9; Кротов М.И. Межпарламентское сотрудничество и формирование экономического союза в СНГ // Вестник Межпарламентской Ассамблеи. 1993. № 2; Моисеев Е.Г. Правовой статус Содружества Независимых Государств. М., 1995 и др.

${ }^{16}$ См.: Международные парламентские организации: Справочник. М., 1994. 29 с.; Международные парламентские организации: Справочник. М., 1992.63 с.
} 
круг вопросов: понятие и правовая природа, внутренняя структура и членство, классификация и особенности международньх парламентских организаций ${ }^{17}$.

Значительное количество работ по отдельным видам межпарламентских организаций написано зарубежными авторами. Из обобщающих работ можно назвать статьи X. Клебеса ${ }^{18}$ и Дж. Д. Пристмэна ${ }^{19}$. Так, Х. Клебес весьма подробно анализировал правовую природу межпарламентских организаций. Работа Дж. Д. Пристмэна положила начало систематизированному изучению и классификации международных парламентских организаций.

Если первая межпарламентская организация появилась немногим более столетия назад, то в начале XXI века такие организации стали уже органическим, неотьемлемым элементом всей структуры международных отношений и оказывают на них далеко не маловажное влияние. В этом своем качестве международные парламентские организации, естественно, привлекают к себе все болышее внимание парламентариев, политиков, общественных и государственных деятелей, ученых и простых людей.

Межпарламентские связи являются составной частью межгосударственных отношений. Они оказывают существенное влияние на содержание, уровень, динамику и перспективу развития современных международных отношений. Действительно, в достаточно многообразном арсенале форм и методов межпарламентских связей особую, позитивную нишу занимают непосредственные контакты парламентариев разных стран друг с другом. Налаженность и регулярность таких связей свидетельствуют о взаимном интересе, стремлении лучше

${ }^{17}$ Хабаров С.А. Международные межпарламентские организации. Автореф. дис. ... канд. юрид. наук. М., 1997. 25 с.; Хабаров С.А. Международные парламентские организации: правовые аспекты. М., 1994. 180 с.; Хабаров С.А. Международные парламентские организации: правовые аспекты. М., 1995. 251 с.; Хабаров С.А. Европейские парламентские организации (правовые аспекты) // Государство и право. 1997. № 1. С. 106-1 13. См. также: Кутейников А.Е. Национальныепарламенты и международные организации // Вестник Межпарламентской Ассамблеи. 1999. № 2. С. 120-135.

${ }^{18}$ Cm.: Klebes H. The Development of International Parliamentary Institutions // Constitutional and Parliamentary Information ASGP. Geneva 1st Series. № 159/1st Halfyear 1990. P. 77-100; Klebes H. Les institutions parlementaires internationales // Revue Generale de Droit international Public. Paris. Tome 92. 1988. № 4. P. 815-880.

${ }^{19}$ Priestman J.D. Relations between National Parliaments and International Parliamentary Assemblies //Constitutional and Parliamentary Information ASGP. Geneva. 3rd Series. № 124/ 4th Quarter. 1980. P. 102-155. 
понять друг друга, установить взаимное доверие, внести вклад в развитие сотрудничества. Личные контакты и профессиональные связи парламентариев, их участие в переговорном процессе на межгосударственном и иньх уровнях нередко нейтрализуют порой возникающую отчужденность, непонимание характера происходяпци в той или иной стране событий, существующих в различных слоях общества настроений. Они также могут способствовать развитию парламентской дипломатии, сближению позиций и достижению договоренностей, вести к созданино отвечающего взаимным интересам нормативно-правового регулирования межгосударственньх отношений.

Помимо индивидуально проявляемой отдельными парламентариями в этом направлении инициативы общепризнанным эффективным путем развития межпарламентского сотрудничества, подтвердившим свою результативность международной практикой, являются межпарламентские организации парламентариев различных государств.

Одной из характерных черт современных международных отношений является все более возрастающая роль межпарламентских организаций. В этом находят выражение усложнение и расширение сферы международных отношений, обусловившие развитие как многосторонней парламентской дипломатии, так и более широкого межпарламентского сотрудничества на двустороннем уровне, в том числе в рамках межпарламентских организац ий в различных сферах социалынойжизни.

Отличительной особенностью современной международной жизни является существование многочисленньх межпарламентских организаций и продолжающийся их рост. В этом выражаются все возрастающее влияние парламентов на внешнюю политику, усиление роли парламентского измерения в международных отношениях.

По нашим подсчетам, число официально зарегистрированньх межпарламентских организаций составляет ныне более $70^{20}$. Определяющие тенденции развития современных международньх отношений со всей их сложностью и противоречивостью обусловливают создание новых и эволюцию существующих межпарламентских организаций. Очевидно, что количественный рост международных парламентских организаций и расширение сферы их деятельности, в свою очередь, воздействуют на структуру и систему международных отношений. Деятельность межпарламентских организаций специфически отражаст итрансформирует международныс проблемы, их эволюцию.

\footnotetext{
${ }^{20}$ См.: Саидов А.Х. Межпарламентские организации мира: Справочник. М., 2004.
} 
Следует подчеркнуть, что в рамках программы учебного курса международного публичного права не уделяется вообще внимания межпарламентским организациям. В рамках преподавания курса «Право международных организаций» основное внимание уделяется международно-правовым аспектам деятельности универсальньх, региональных и некоторых субрегиональных международных межправительственных организаций. Вместе с тем нынешнее развитие международных отношений и возрастаюшая роль в них межпарламентских организаций требуют, чтобы деятелыности международных парламентских организаций было уделено адекватное внимание при преподавании международно-правовых дисциплин.

В программах учеб̆ного курса «Парламентское право России» имеется специальная тема «Межпарламентское сотрудничество» ${ }^{21}$. В учебниках по европейскому праву имеются темы, посвященные Европейскому парламенту 22.

Интенсивная межлународная парламентская практика, во-первых, позволяет обратиться к изучению таких явлений международно-правовой действительности, которые ранее не охватывались проблематикой науки международного права; во-вторых, помогает взглянуть под особым углом зрения на ряд традиционных проблем права международных организаций; в-третьих, потребует методологических и учебно-методических разработок в области парламентоведения. В обновленном виде происходит соединение эмпирического и национального уровней парламентских исследований с теорией права международных организаций среднего уровня и системой науки международного права высшего уровня.

Признание международного парламентского права в качестве самостоятельной отрасли (подотрасли) международного права обусловлено рядом объективных факторов, хотя, разумеется, нельзя сбрасывать со счетов и внутреннюю логику развития науки международного права, и ее рост.

Объективными предпосылками все усиливающегося значения международного парламентского права в современном мире являготся:

${ }^{21}$ В программах учебного курса «Парламентское право России» имеется специальная тема «Межпарламентское сотрудничество».

${ }^{22}$ См.: Топорнин Б.Н. Европейское право: Учебник. М., 1998. С. 324-354; Европейское право: Учебник / Отв. ред. Л.М. Энтин. М., 2000. С. 266-285; Основы права Европейского Союза: Учебное пособие / Под ред. С.Ю. Кашкина. М., 1997; Право Европейского Союза: Учебник / Под ред. С.Ю. Кашкина. М., 2002. С. 253-277. 
во-первых, увеличение количества и повышение роли международных межпарламентских организаций;

во-вторых, усиление вовлеченности парламентов в процесс законотворчества на национальном, региональном и глобальном уровнях;

в-третьих, становление парламентской демократии ${ }^{23}$ как важной составной части международного сотрудничества и глобального управления;

в-четвертых, становление и развитие парламентского измерения международных отношений ${ }^{24}$;

в-пятых, укрепление взаимодействия межтународных межпарламентских организаций с ООН и между собой;

в-шестых, усиление внимания парламентариев, граждан, институтов гражданского общества и средств массовой информации к международным межпарламентским организациям.

К числу факторов, которые можно назвать субъективными, относится широкое развитие международных научных контактов. Многочисленные конгрессы, симпозиумы, «круглые столы», конференции по парламентской проблематике стали ньпе весьма важным фактором функционирования и развития международного парламентского права. Все это требует проведения широких исследований по международному парламентскому праву, во-первьх, в теоретических целях, вовторьх, в практико-прикладном плане совершенствования парламентских институтов и процедур и, наконец, в-третьих, в целях взаимного использования международного и национального парламентского опьта.

Современное развитие межпарламентских организаций указываст на будущее направление международного парламентского сотрудничества, которое через постепенное вовлечение все новых сфер и аспектов в орбиту своей деятельности может привести к требованиям расширения инструментария и полномочий межпарламентских организацй̆.

Центром современного международного сотрудничества является ООН. Все большее значение приобретает парламентское измерение ${ }^{23}$ CM.: Strasbourg Conference on Parliamentary Democracy (1st: 1983). Strasbourg: Council of Europe, 1984, 298 p; Conférence de Strasbourg sur la démocratie (2; 1987). Strasbourg: Parlement européen, Assemblée parlementaire du Conseil de l'Europe, 1987, 359 p.; Conférence de Strasbourg sur la démocratie parlementaire $(3 ; 1991)$. Strasbourg: Parlement européen, Assemblée parlementaire du Conseil de l'Europe, 1992, 300 p.

${ }^{24} \mathrm{Cм.:} \mathrm{Саидов} \mathrm{А.Х.} \mathrm{Парламентское} \mathrm{измерение} \mathrm{международных} \mathrm{отношений} \mathrm{//} \mathrm{Между-}$ народное публичное и частное право, 2005. № 1. С. 40-46. 
деятельности ООН. В 1996 году было подписано Соглашение о сотрудничестве между Организацией Объединенных Наций и Межпарламентским Союзом (МПС) $)^{25}$, которое служит фундаментом современного сотрудничества между двумя этими организациями. В соответствии с этим Соглашением ежегодно Генеральный секретарь ООН представляет Генеральной Ассамблее доклад о различных аспектах сотрудничества между ООН и МПС и в повестку дня каждой сессии Генеральной Ассамблеи включается пункт «Сотрудничество между Организацией Объединенных Наций и Межпарламентским Союзом» ${ }^{26}$.

Проведение ежегодных парламентских слушаний с участием членов парламентов, приезжающих для участия в сессии Генеральной Ассамблеи ООН, вошло в практику и позволяет членам парламентов всех стран мира лучше понять цели и методы деятельности ООН, давая при этом возможность выслушать мнения парламентариев по существу вопросов, которыми она занимается. Генеральная Ассамблея ежегодно обсуждает усилия, предпринимаемые Межпарламентским Союзом по обеспечению вклада парламентских структур в проведение наиболее важных мероприятий ООН.

Первая Конференция председателей национальных парламентов в связи с Ассамблеей тысячелетия ООН проходила в зале Генеральной Ассамблеи с 30 августа по 1 сентября 2002 года и послужила первым этапом проведения Саммита тысячелетия. В конференции приняли участие около 150 председателей национальных парламентов из 138 стран и примерно 1000 парламентариев. Конференция приняла Декларацию «Парламентское видение международного сотрудничества на пороге третьего тысячелетия», в которой председатели националыных парламентов заявили о своей приверженности международному сотрудничеству, о главной роли ООН в нем и подтвердили свою убежденность в том, что ООН должна оставаться основой эффективного глобального сотрудничества, а также необходимость более активного участия парламентов в международных делах, и в частности в работе системы $\mathrm{OOH}^{27}$.

Вторая всемирная конференция председателей национальных парламентов в связи с 60-летием ООН проходила 7-9 сентября 2005 года

${ }^{25}$ См.: Док. A/51/402, приложение.

${ }^{26} \mathrm{CM} .:$ Док. A/RES/54/12.

${ }^{27}$ CM.: Conference of Presiding Officers of National Parliaments. Lausanne: InterParliamentary Union, 2001.202 p. 
в Нью-Йорке. Целью конференции явилось ознакомление ООН с ролью высших национальных законодательных органов в деле обеспечения международной, религиозной и национальной безопасности, борьбы с терроризмом, развития демократии и соблюдения прав человека. На конференцци единодушно была отмечена необходимость обобщения опыта национальных парламентов и создания механизмов парламентского сотрудничества в условиях глобализации.

В 2000 г. на Саммите тысячелетия было принято решение о «дальнейшем укреплении сотрудничества между ООН и национальными парламентами через их всемирную организацию - Межпарламентский Союз - в различных областях, включая мир и безопасность, экономическое и социальное развитие, международное право и права человека, демократию и гендерные вопросы» ${ }^{28}$.

Всемирная комиссия по социальным аспектам глобализации, созданная МОТ, призьвает «к созданию Глобальной парламентской группы, ответственной за обеспечение согласованности и последовательности глобальной экономической и социальной политики, которая должна будет обеспечивать комплексный надзор за деятельностью крупных международных организаций системы ООН, бреттон-вудских учреждений и ВТО», а также Межпарламентский союз и другие парламентские форумы «к поиску путей мобилизации общественного мнения в отношении социального измерения глобализации» ${ }^{29}$.

Межпарламентский Союз играет особую роль как инструмент равноправного и взаимообогащающего диалога и обмена опытом, как организация парламентов мира, объединенная на основе демократии, парламентской солидарности, подотчетности избравшим их народам. МПС из союза парламентских групп превратился в международное объединение парламентов мира, действующее на основе все более тесного и расширяющегося сотрудничества с ООН. Он выступает в качестве генеральной ассамблеи парламентов планеты. МПС-универсальная парламентская организация, главной целью которой является сближение парламентов всех стран мира в деле укрепления международного мира и безопасности, формой коллективного обсуждения актуалынх проблем современности.

МПС как всемирная организация парламентов играет важную роль в развитии мира и международного сотрудничества в соответствии и в

${ }^{28} \mathrm{Cм.:} \mathrm{Декларация} \mathrm{тысячелетия} \mathrm{Организации} \mathrm{Объединенных} \mathrm{Наций} \mathrm{//} \mathrm{Док.A/55/L.2.}$ ${ }^{29}$ Справедливая глобализация: создание возможностей для всех. Женева, 2004. С. 135. 
развитие целей и принципов ООН (ст. 1 Соглашения о сотрудничестве $\mathrm{OOH}$ - МПС). Деятельность МПС охватывает широкий круг вопросов, все более совпадающий с основными направлениями деятельности ООН: это проблемы мира и безопасности, экономическое и социальное развитие, международное право и права человека, укрепление демократии и законности, улучшение положения женщин, диалог между цивилизациями и другие.

В настоящее время Межпарламентский Союз выполняет следующие функции по укреплению сотрудничества между ООН и национальными парламентами:

во-первых, информирование ООН о мнениях народов во всем их разнообразии, которые выражаются в ходе парламентских прений и обсуждений в МПС;

во-вторых, содействие информированию парламентов о международных соглашениях, заклочаемьх ООН и через ее программу, и принятиго мер в их поддержку;

в-третьих, содействие реализации международных соглашений за счет активизации деятельности парламентов и их членов по мобилизации общественности и организации на национальном уровне мер в подлержку межлународных действий;

в-четвертых, подготовка анализов и докладов по вопросам парламентской деятельности, имеюших отношение к работе ООН, особенно в тех областях, где МПС располагает особым опытом;

в-пятых, оказание подлержки парламентом в целях нарашивания их возможностей по выполнению на национальном уровне законодательных и контрольных функций в отношении вопросов, относящихся к международному сотрудничеству в рамках $\mathrm{OOH}^{30}$.

ООН стремится укреплять парламентский аспект своей деятельности, сотрудничать с национальными парламентами через Межпарламентский союз. Генеральная Ассамблея признала уникальный статус МПС как всемирной организации, представляющей национальные парламенты $^{31}$, а также межгосударственный характер $\mathrm{MПC}^{32}$. Исходя из этого в 2002 году Межпарламентскому Союзу предоставлен статус наблюдателя Генеральной Ассамблеи $\mathrm{OOH}^{33}$.

\footnotetext{
${ }^{30} \mathrm{Cм.:} \mathrm{Док.} \mathrm{А/55/996.}$

${ }^{31}$ См.: Док.А/55/19.

${ }^{32} \mathrm{CM}$ : : Док.А/56/35.

${ }^{33} 108$ th IPU Conference and Related Meetings. Results of the proceedings. Santiago de Chili (Chili), 3-12 April, 2003. Geneve. 2003. P. 8-9.
} 
Новый статус МПС при Генеральной Ассамбллее ООН позволяег парламентариям принимать более активное участие в решении важнейших проблем современности - мира, безопасности, экономического и социалыного развития, прав человека и гендерных проблем. МПС полностью разделяет принципы и цели Устава, и его деятельность направлена на содействие реализации целей и задач ООН. Все это усилит парламентское измерение деятельности ООН.

В настоящее время продолжает расти авторитет МПС, который превращается в объединение парламентов мира, укрепляются связи и расширяется сотрудничество МПС с ООН. Особенно важным становится то влияние, которое Межпарламентский Союз оказывает на развитие международного права и национальных законов.

Действительно, к началу XXI века накоплен значительный национальный и международный нормативно-правовой массив, существенный опыт развития парламентаризма, самобытные национальные парламентские традиции и обычаи, а также огромный доктринальноисточниковедческий материал о парламенте. Со всем этим в свою очередь связано увеличение внимания к теоретическому осмыслению международного парламентского права, его роли, возможностей, результатов, месту в теоретико-методологическом арсенале современной науки международного права. Нельзя не отметить, что вопросы международных межпарламентских организаций на сегодня разработаны в науке международного права полнее, чем в какой-либо другой. Это связано с тем, что в сфере юридической науки парламентские исследования не только играют научно-познавательную роль, но и несуг на себе значительную практико-прикладную нагрузку.

Международное парламентское право трудно полностыо отделить от права международных организаций, так как, во-первых, оно выходит из недр права международных организаций, является продуктом его развития, во-вторых, нормы права международных организаций составляют неотьемлемую часть международного парламентского права, его основных начал. Поэтому есть все основания считать международное парламентское право подотраслью права международных организаций.

Следует, однако, отметить, что авторы современных учебников по международному праву (и России, и зарубежных стран) не спешат признавать международное парламентское право в качестве подотрасли права международных организаций. Несмотря на это международное 
парламентское право не только все болыше проявляет все качества самостоятельной отрасли международного права, но и все больше обособляется от права международных организаций.

Здесь надо иметь в виду тенденцию развития отраслей современного межлународного права за последнюю четверть века. Бурный рост количества отраслей международного права связан с возникновением новых направлений и сфер международно-правового регулирования общественных отношений. В силу этого как о самостоятельной отрасли международного права заговорили в последнее время о таких объединениях международно-правовых норм, которые ранее считались лишь институтами тех или иных отраслей международного права. Имеются в виду международное право прав человека, право международной безопасности, международное право развития, право международной ответственности, международное пенитенциарное право, международное право религиозных конфессий и др. Все это характеризует новейшие тенденции развития современной системы международного права, ее основные черты. Показательно, кстати, и то, что ученые-юристы все чаще вычленяют и новые институты, подотрасли и отрасли в международном праве, и только дальнейшая дискуссия покажет плодотворность таких попыток.

Если обратиться к учебной литературе по международному публичному праву, следует заметить, что учебные курсы, в особенности написанные авторитетными учеными, будучи рассчитанными в основном на использование в учебном процессе, и в науке международного права очень часто играют системообразующую роль.

Но надо признать, что при рассмотрении отрасли права международных организаций, тем более системы международного публичного права в целом, ни о каких межлународных межпарламентских организациях или международном парламентском праве речь не идет. Несомненно, что международное парламентское право должно рассматриваться в рамках права международных организаций. Его рассмотрение как самостоятельной подотрасли права международных организаций во многом зависит от развития и повьшения роли международных межпарламентских организаций в мировой политике в условиях глобализации, а также последовательности осмысления этих явлений наукой международного права.

Следует обратить внимание, что специфика международного парламентского права заключается в его двухуровневости и объясняется 
многогранностью процессов развития международных парламентских отношений. Но в отличие от других двухуровневых отраслей (подотраслей) международного права своеобразие предмета международного парламентского права в том, что международные межпарламентские организации, как универсальные, к которым относится Межпарламентский союз, так и региональные, такие как Европейский парламент, Латиноамериканский парламент, не соподчинены, не составляют единого структурированного и организационного механизма. Необходимо отметить, что для регионалыного уровня международного парламентского права характерно болышое разнообразие международно-правовых норм, в том числе и содержательное отличие правоположений, регламентирующих аналогичные правоотношения. Это, очевидно, объясняется многообразием подходов региональных международных межпарламентских организаций к регламентации тех или иных международных отношений. Одним словом, окончателыное формирование межлународного парламентского права как подотрасли права международных организаций невозможно без осмысления как в теоретическом, так и в практическом плане деятельности региональных международных межпарламентских организаций.

Можно выцелить следующие компоненты международного парламентского права:

во-первых, объектно-предметная сфера; это сами международные парламентские отношения, т.е. объект нормативно-правового регулирования в международной парламентской системе;

во-вторых, институционально-субьектная сфера; к этой сфере относятся все участники международной парламентской системы, т.е. международыые парламентские организации, националыные парламенты, парламентарии и другие субъекты современного международного права;

в-третьих, регулятивная (или нормативно-источниковедческая сфера); к ней относятся все виды/группы норм, задействованных в регулировании международной парламентской системы, а именно: нормы национального парламентского права, международно-правовые нормы, нормы «мягкого права», различного рода неправовые нормы;

в-четвертых, функциональная сфера; к этому компоненту международного парламентского права относятся парламентские процедуры, традиции, обычаи, направленныс на обеспечение эффективности парламентской системы; 
в-пятых, информационно-образовательная сфера; речь идет об информировании населения о международной и национальной парламентской практике, научном исследовании и преподавании международного парламентского права, издание книг и журналов по парламентской проблематике.

Международное парламентскоеправо направлено на регулирование мирового парламентского пространства, которое многогранно, имеет много аспектов, связывает воедино национальные, региональные и универсалыные парламентские организации. Мировоепарламентскоепространство является подсистемой глобалыной международной системы.

Есть основания различать три блока источников международного парламснтского права:

1) нормы международного «Твердого» права, т.е. основные принщипы международного права, международные договоры и международный обычай;

2) нормы межлународного «мягкого» права, т.е. рекомендательнопроцедурные нормы;

3) доктрина.

Для эффективного применения на практике международного парламентского права целесообразно разработать его систему. По нашему мнению, она должна представлять из себя совокупность следующих институтов:

1. Понятие, предмет, сущность, особенности и система международного парламентского права;

2. Субъъекты международного парламентского права;

3. Источники международного парламентского права;

4. Принщипы международного парламентского права;

5. Соотношение межлународного парламентского права с международным публичным правом, правом международных организаций и национальным парламентским правом;

6. Международные межпарламентские организации как субъекты международного публичного права;

7. Формы международного сотрудничества и межпарламентских связей национальных парламентов;

8. Международно-правовая зацита прав человека в рамках деятельности международных межпарламентских организаций;

9. Внутреннее право и внешнее право международных межпарламентских организаций; 
10. Общая характеристика и особенности универсальных и региональных межпарламентских организаций: Межпарламентский союз, Европейский парламент, Парламентская ассоциация Содружества, Латиноамериканский парламент, Парламентская Ассамблея африканского союза, Межпарламентская ассамблея СНГ и др.

Глобалыные вызовы человечеству обусловливают взаимозависимость государств, особенно в таких областях, как торговля, финансы, экология, технология, безопасность, борьба с международным терроризмом $^{34}$. Такая взаимозависимость государств диктует необходимость опираться и на межпарламентские организации.

Реалии начала XXI века обуславливают более активное участие парламентариев в решении мировых проблем современности в условиях глобализации, расширение сотрудничества между ООН и Межпарламентским Союзом, а также различными межпарламентскими организациями мира. Глобализация становится магистралыным направлением планетарного развития в XXI веке. И это требует особого внимания парламентариев. Парламентарии мира должны употребить весь свой авторитет и противодействовать попьткам разрушения демократических и духовных ценностей, национальных традиций, принципов взаимного уважения, которые формировались веками и составляют уникальное богатство народов мира.

Демократизация и гуманизация межлународных отношений, интеграция межпарламентских связей - тоже процесс глобальный. Межпарламентское сотрудничество как средство гармонизации националыных и глобальньх тенденций приобретает особую значимость.

Возрастание роли парламентаризма и парламентов- объективное и закономерное следствие мирового развития. Парламентарии являются основными авторами положений международного права, имеющих универсальное значение. Они воплощение суверенитета народа и могут со всей легитимностью вносить вклад в процесс выражения воли государства в современном межлународном праве.

В XXI веке очевиднес становится роль представительной власти, парламентариев, являгецися альтернативой произволу, диктату и беззаконию. Парламентарии играют особую роль в поиске ответов на вызовы современности, к которым относятся глобализация, международный терроризм, проблемы экологии и устойчивого развития.

\footnotetext{
${ }^{34}$ См.: Лукашук И.И. Глобализация, государство, право, XXI век. М., 2000.
} 
Парламенты находятся в центре проблем, волнующих сегодня мировое сообщество. Важна роль парламентариев в качестве законных народных представителей и в качестве связующего звена между потребностями граждан и соответствующей правительственной политикой, как на национальном, так и на международном уровне.

Современное понимание процесса глобализации подразумевает также реализацию всего многообразия прав и интересов граждан средствами парламентаризма. В этих условиях возрастает роль национальных парламентов. Парламент находится в центре пересечения тенденций развития национального законодательства и развития глобальных процессов, затрагивающих интересы суверенных государств. Поиск компромисса между принятием прогрессивного содержания глобальных процессов и сохранением собственных национальных интересов - важная задача для парламентов всех стран.

В докладе Группы видных деятелей по вопросу отношений между ООН и гражданами «Более систематическое привлечение парламентариев к деятельности Организации Объединенных Наций» отмечается, что «укрепление связей Организации Объединенных Наций и парламентариев могло бы в значительной степени способствовать преодолению нехватки демократических начал в системе глобального правления». Группа предлагает стратегию, предусматривающую четыре элемента:

1) обеспечить более систематическое рассмотрение вопросов, которыми занимается ООН, национальными парламентами;

2) добиться того, чтобы участвующие в мероприятиях ООН парламентарии играли более заметную роль;

3) привлекать сами парламенты к обсуждению на международном уровне;

4) создать в рамках ООН институциональную структуру для привЛечения парламентариев ${ }^{35}$.

Таким образом, становится все более очевидным приобретение парламентом свойств международного характера. Это связано не только с расширением его внешнеполитической деятельности, но и с широким распространением межпарламентских организаций, которые как бы раздвигают внутренние рамки парламентской деятельности. Повсеместное расширение парламентского движения и признание в мире идей и принципов парламентаризма придают парламентской деятельности ${ }^{35}$ Док. А/58/817. 
значение мощного фактора устойчивого развития и социального прогресса, а также формирования справедливого гражданского общества. Воздействуя на граждан, общество и государство, современные парламентские организации в свою очередь испытывают их мощное влияние $^{36}$. Межпарламентские организации выступают своего рода «парламентским зеркалом» современного мирового общества, показателем устойчивости и эффективности парламентских институтов как ценности демократии.

Несомненный интерес представляет вопрос о взаимосвязи норм международного и националыного парламентского права. В области межлународного парламентского права такая взаимосвязь проявляется прежде всего в том, что нормы национального парламентского права призваны определить способы приведения в действие норм международного парламентского права в рамках национальной правовой системы. При этом под способом приведения в действие норм международного парламентского права следует понимать способы исполнения государством взятого на себя межлународно-правового обязательства, и не способ придания нормам международного права силы внутригосударственного нормативно-правового акта, форму превращения международно-правовой нормы, обязательной для государства в целом, в норму национального законодательства, обязательного для всех граждан и государственных органов.

В заключение можно сделать следующие выводы.

Во-первых, международное парламентское право - это система международно-правовых норм, регулирующих международные парламентские отношения.

Во-вторых, международное парламентское право - это подотрасль права международных организаций, и оно рассматривается как право публичное.

В-третьих, международное парламентское право имеет свой предмет регулирования и свои особенности.

В-четвертых, международное парламентское право тесно взаимодействует с другими институтами и отраслями международного права и националыного парламентского права, и более того - переплетается с ними.

В-пятых, объектом регулирования при помощи международного парламентского права являются международные парламентские отношения, но не вся совокупность таких отношений, а только часть их.

\footnotetext{
${ }^{36}$ См.: Котелевская Н.А. Современный парламент //Государство и право. 1997. № 3. С. 13.
} 
В-шестых, международное парламентское право осуществляет целенаправленное воздействие на поведение национальных парламентов и международных межпарламентских организаций.

В-седьмых, международное парламентское право обладает признаками системности. Оно представляет собой систему международноправовых норм, объединенных единством и взаимосвязями, внутренней организацией, состоящей из различньх компонентов, - норм, институтов и субинститутов. Взаимосвязанность структурных компонентов преврацает международное парламентское право в целостное правовое явление, в подотрасль права международных организаций.

В-восьмых, структуродержащим компонентом системы международного парламентского права являготся его принципы. Специалыные («подотраслевые») принципы международного парламентского права - это наиболее общие нормы, обладающие всеобщим признанием и высокой юридической силой. Принципы международного парламентского права вытекают из общих принципов международного права и специальных принципов права межлународных организаций.

В-девятых, важную роль в условиях глобализации играют международные межпарламентские организации. Можно утверждать, что метод регулирования при помощи международных межпарламентских организаций, метод многостороннего регулирования международных парламентских отношений оказался наиболее востребованным. Международные межпарламентские организации являготся субъектами международного права и, соответственно, права международных организаций.

В-десятьх, международное парламентское право весьма существенно влияет на характер и содержание национального парламентского права. Национальные парламентские нормы, принципы, традиции, обычаи, процедуры в последнее время заметно унифицируются. Международное парламентское право и национальное парламентское право образуют глобальную международную парламентскую нормативную систему. Взаимное влияние, переплетение двух правовых систем в эпоху глобализации постепенно ведет к их новому качеству - неразрывному единству, в котором, тем не менее, эти системы сохранягося как самостоятельные и автономные. 
Итак, международное парламентское право является «производной» от международного публличного права. Оно является подотраслью права межлународных организаций ${ }^{37}$.

Формирование международного парламентского права как подотрасли права международных организаций опирается на принципы международного публичного права, а также на общие положения национального парламентского права. Развивать международное парламентское право исключительно в недрах международного права бесперспективно. Научный анализ норм международного парламентского права требует знания инструментария как межлународного права и права межлународных организаций, так и национального парламентского права.

Исследование проблем международного парламентского права может дать положительные результаты дыя парламентской практики лишь в том случае, если оно будет опираться на основы современного международного публичного права и их проявление в межпарламентских отношениях, а также основы национального парламентского права.

\footnotetext{
${ }^{37}$ Впрочем, Т.Н. Нешатаева считает, что право международных организаций не входит в международное публичное право. См.: Нешатаева Т.Н. Международные организации и право. М., 1998. С. 57-58. С таким мнением согласиться нельзя, ибо межправительственные организации являются субъектами международного публичного права (это признает и сама Т.Н. Нешатаева), и следовательно, статус, порядок создания и деятельность их регламентируются основными принципами и нормами международного публичного права. См., также: Международное публичноеправо: Учебник / Отв. ред. К.А. Бекяшев. 3-еизд. перераб. и доп. М., 2004. С. 341.
} 